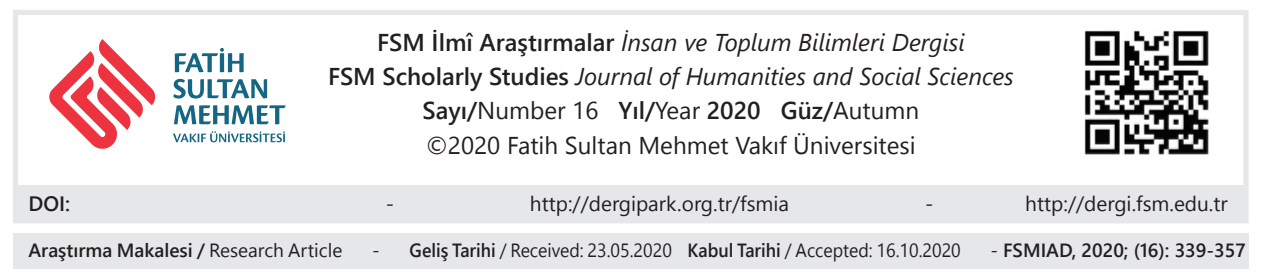

\title{
Erkeksi Davranış Ölçeğinin Türk Kültürüne Uyarlanması: Geçerlik ve Güvenirlik Çalışması
}

Hakan Sarıçam*
Aykut Sığın

\section{Öz}

Bu çalışmanın amacı, Erkeksi Davranış Ölçeği’nin (EDÖ) üniversite öğrencilerinde geçerlik ve güvenirliğini sınamak ve bunun yanında, ölçeğin psikometrik özelliklerini incelemektir. Araştırmada çalışma grubunu yaşları 18 ile 41 arasında olan toplamda 602 üniversite öğrencisi oluşturmuştur. Açıklayıcı Faktör Analizi sonuçlarına göre Erkeksi Davranış Ölçeği’nin Türkçe formunun orijinal halindeki gibi dört boyuta sahip olduğu ve bu modelin ölçtüğü özellikle ilgili toplam varyansın \%56.50'sini açıkladığı anlaşılmıştır. Doğrulayıcı Faktör Analizi sonucu ölçeğin uyum iyiliği değerleri $\chi^{2} / \mathrm{sd}=2.56$, RM$\mathrm{SEA}=.072, \mathrm{CFI}=.92, \mathrm{GFI}=.90, \mathrm{IFI}=.92, \mathrm{NNFI}=.90$ ve $\mathrm{SRMR}=.072$ şeklinde hesaplanmıştır. Bunun yanı sıra, madde faktör yükleri .40 ile .77 arasında sıralanmaktadır. Ölçüt bağıntılı geçerlik çalışmasında Erkeksi Davranış Ölçeği ile Bem Cinsiyet Rolleri Ölçeği arasında pozitif ilişkiler saptanmıştır. Cronbach alfa iç tutarlık katsayısı Başarıya Adanma alt boyutu için $\alpha=.84$; Kısıtlı Duygusallık alt boyutu için $\alpha=.77$; Kısıtlanmış Sevgi alt

* Doç. Dr., Sivas Cumhuriyet Üniversitesi Eğitim Fakültesi Rehberlik ve Psikolojik Danışmanl1k Anabilim Dalı, Sivas/Türkiye, hakansaricam@gmail.com, orcid.org/0000-0002-8723-1199

**: Dr. Öğr. Üyesi, Aksaray Üniversitesi Fen Edebiyat Fakültesi Sosyoloji Bölümü, Aksaray/Türkiye, aykutsgn@gmail.com, orcid.org/0000-0002-1197-552X 
boyutu için $\alpha=.80$; Abartılı Özgüven ve Kontrol alt boyutu için $\alpha=.73$ ve ölçeğin bütünü için $\alpha=.81$ olarak tespit edilmiştir. Düzeltilmiş madde toplam korelasyon katsayıları .41 ile .68 arasında değişiklik göstermektedir. Sonuç olarak, Erkeksi Davranış Ölçeği'nin yetişkin Türklerde kullanılabilecek geçerli ve güvenilir bir ölçme aracı olduğu anlaşılmıştır.

Anahtar Kelimeler: Erkeklik, erkeksi davranış, geçerlik, güvenirlik.

\title{
The Adaptation of the Masculine Behavior Scale to the Turkish Culture: A Validity and Reliability Study
}

\begin{abstract}
The aim of the current study is to test the reliability and validity of the Masculine Behavior Scale (MBS) with Turkish university students and to check out its psychometric values. The participants were selected among a total of 602 university students aged from 18 to 41. In Explanatory Factor Analysis, it was revealed that the Turkish form of Masculine Behavior Scale had four-dimensions like the original instrument and this model explained $56.50 \%$ of total variance related to the attribute it measured. In Confirmatory Factor Analysis, fit index values were calculated as $\chi^{2} / \mathrm{df}=2.56$, RMSEA $=.072, \mathrm{CFI}=.92$, $\mathrm{GFI}=.90, \mathrm{IFI}=.92, \mathrm{NNFI}=.90$, and $\mathrm{SRMR}=.072$. Additionally, factor loadings lined up between .40 and .77. In the concurrent validity, Masculine Behavior Scale had positive significant relationships with Bem Sex Roles Inventory. Cronbach alpha internal consistency coefficient was attained as $\alpha=.84$ for Success Dedication subscale, $\alpha=.77$ for Restrictive Emotionality subscale, $\alpha=.80$ for Inhibited Affection subscale, $\alpha=.73$ for Exaggerated Self-reliance subscale, $\alpha=.81$ for whole scale. Corrected item-total correlations lined up between .41 and .68. In conclusion, these findings indicated that Masculine Behavior Scale could be used with Turkish adults as a valid and reliable assessment instrument.
\end{abstract}

Keywords: Masculinity, masculine behavior, validity, reliability. 


\section{Giriş}

Ataerkil ya da patriyarkal olarak adlandırılan düzen, yaşadığımız dünyanın hemen her alanında kendisini bir şekilde gösterebilen; erkeğin, iktidarı büyük ölçüde elinde tuttuğu fikirler ve pratikler bütünü veya toplumsal ayrıcalıklar anlamında daha ön planda ve öncelikli olduğu bir ideoloji olarak tanımlanabilecek bir toplumsal alg1 sürecine işaret etmektedir. Söz konusu düzen kendisini özelde siyaset, ekonomi, din, hukuk, eğitim gibi toplumsal kurumlarda hissettirirken genelde de toplumsal yapının tamamına nüfuz etmiş bir şekilde doğrudan veya dolaylı yollardan algılanabilmektedir. Bu bağlamda, kadın hareketinin temelde mücadele ettiği şey, ataerkil zihniyet olmuş, özellikle ikinci dalga feministler "Özel olan politiktir!" sloganıyla bu anlayışın ve ona bağlı olarak ortaya çıkan toplumsal cinsiyet eşitsizliğinin "özel alan" olarak tanımlanan ev içerisinde üretilmeye başladığına dikkat çekerek ataerkilliğin toplumun en küçük yapı birimi veya minyatürü olan ailede başladığını ortaya koymuştur.

Siyaset, ekonomi, eğitim, medya gibi alanlar incelendiğinde de ataerkil düzenin toplumsal cinsiyet eşitsizliğini ürettiğine yönelik emarelere rastlamak zor değildir. Örneğin, siyasi arenada parlamenter sistemle yönetilen ülkelere bakıldığında kadın temsilinin ortalama olarak \%17.4'te kaldığını; ekonomiye bakıldığında 3.1 milyar yoksul insanın \%70'inin kadın olduğunu; eğitime bakıldığındaysa okuryazar olmayanların yaklaşık 3'te 2'sinin kadın olduğu görmek mümkündür ${ }^{1}$. Medya, erkek üstünlügünün bütün çıplaklığıyla gözler önüne serilmesi itibariyle ayrıca dikkat çekilebilecek bir alandır. Bu duruma bir örnek vermek gerekirse, The Global Media Monitoring Project 2015'e (Küresel Medya İzleme Projesi 2015) bakılması yeterli olacaktır. Araştırmaya² göre, 2015 yıl1 itibariyle ${ }^{3}$ televizyon haberciliğinde erkekler \%76, kadınlar ise \%24 oranında varlık göstermiştir.

Ataerkil sistem eleştirisinin kadın çalışmalarıyla başladığını söylemek mümkünse de bu eleştirinin günümüzde yalnızca kadın üzerinden yürütülmediği söylenebilir. Örneğin, queer kuramc1lar heteronormativite ve heteronormatif düzenin ötekileştirdiği cinsellikler üzerinden bir anlamda ataerkil dayatmayı

1 M. D. Bal, "Toplumsal Cinsiyet Eşitsizliğine Genel Bakış”, Kadın Sağlı̆̆ı Hemşireliği Dergisi, 1, 1, 2014, s. 15-28.

2 The Global Media Monitoring Project, GMMP 2015 Global, Regional and National Reports, 2015, s. 3.

3 5'er yıllık aralıklarla yürütülen araştırmanın bir sonraki raporlaması 2020 yılı içerisinde gerçekleştirilecek olup şu anki çalışmanın tamamlandığı tarih itibariyle yayınlanmamıştır. 
sorgulamışlardır . Bu noktadan hareketle, heteropatriyarkal anlayış, kadına yönelik cinsiyet ayrımcılığını doğurduğu gibi LGBTİ bireyleri de benzer süreçlerle yüzleştiren toplumsal bir algıdır. Connell ${ }^{5}$ ise eleştiriden öte, tek tür bir erkeklik kavramsallaştırmasının toplumsal gerçekliği yansıtmadığına, bundan dolayı da tekil erkekliği değil, çoğul erkeklikleri tartışmanın gerekliliğine dikkat çekmiş ve bu doğrultuda bir "toplumsal cinsiyet düzeni"nden bahsetmiştir. Toplumsal cinsiyet düzeninin en üstünde yer alan hegemonik erkeklik, ataerkil sistemin erkeğe sağladığı ayrıcalıklardan en fazla pay alan erkeklik türünü tanımlamak için kullanılan kavramsallaştırmayken madun erkeklik kavramı da ataerkilliğin ideal erkeklik sınırlarının dışında kalan erkekleri anlatmaktadır.

Connell'ın kavramsallaştırmasından da anlaşılabileceği üzere, ataerkilliğin eleştirisi söz konusu olduğunda bir toplumsal cinsiyet kategorisi olarak erkeğin değil de toplumsal bir algılayış biçimi olarak "erkek egemen" düzenin eleştirisi yapılmaktadır. Ancak yine de ataerkil ideolojinin en belirgin (ve statükocu mekanizmaların işletilmesi anlamında en aktif) failinin erkek olduğunu söylemek mümkündür. Bundan dolayı erkek, birçok sosyal araştırmanın doğrudan veya dolaylı olarak konusunu oluşturmuş, bunun devamında da 1970'lerde Kuzey Amerika'da erkeklik araştırmaları başı başına bir araştırma sahası olarak kendisini göstermeye başlamıştır. Farklı sosyo-kültürel bağlamlarda erkekliklerin inşası, medyada erkek temsili, erkeklik rolleri, erkek edebiyat, eril dil, zihniyet ve tahakküm gibi meselelere sosyoloji, antropoloji, psikoloji, dilbilim, tarih, edebiyat, reklamcılık gibi çeşitli alanların perspektiflerinden faydalanarak disiplinler arası bir anlayışla yaklaşan erkeklik çalışmalarının Türkiye'de tanınıp yaygınlaşmaya başlamasıysa 2000'li y1llarla birlikte olmuştur.

Erkekliğe ilişkin en temel sorunlardan biri, hangi davranış ve özelliklerin erkeklik normları içerisinde yer alıp hangilerinin dışarıda kaldığını saptamak olmuştur. Değişen sosyo-kültürel bağlamlar ve zamanla birlikte "erkeksi”" olarak nitelendirilen her türlü davranış ve özellik de değişiklik gösterebilmektedir. Örneğin, Kuzey Amerika'da erkeksi olarak nitelendirilen bir davranış Türkiye'de erkeksi olarak değerlendirilmeyebilir veya geçmişte erkeklikle örtüştürülen bir görünüm günümüzde erkeğe ve erkekliğe uygun bulunmayabilir. Ancak yine de kalıp yargısal olarak erkeksi veya kadınsı olarak ele alınabilecek birtakım özelliklerden söz edilebilir. Tablo 1. söz konusu özellikleri göstermektedir.

4 İ. Özküralpli, “Queer Teori”, Toplumsal Cinsiyet Tartışmaları, ed. F. Sayg1lıgil, İstanbul, Dipnot Yayınları, 2018, s. 211-227.

5 R. W. Connell, Masculinities, 2nd ed., Cambridge, Polity Press, 1995. 
Tablo 1: Kalıp Yargısal Olarak Erkeksi ve Kadınsı Olarak Değerlendirilen Kişilik Özellikleri' ${ }^{6}$

\begin{tabular}{ll}
\hline Erkeksi Özellikler & Kadınsı Özellikler \\
\hline Aktiftir & Başkalarının hislerinin farkındadır \\
Lider olarak hareket eder & Düşünceli, anlayışlıdır \\
Maceracıdır & Kolayca ağlar \\
Agresiftir & Kendisini başkalarına adar \\
Hırslıdır & Duygusaldır \\
Rekabetçidir & Büyük bir kriz anında heyecanlanır \\
Kolay kolay pes etmez & Kolaylıkla incinir \\
Dominanttır & Naziktir \\
Üstün hisseder & Ev yaşamına dönüktür \\
Baskı altında dayanıklılık sergiler & Kibardır \\
Bağımsızdır & Çocukları sever \\
Kolaylıkla karar verir & Düzenlidir \\
Kolay kolay etkilenmez & Onaylanmaya ihtiyaç duyar \\
Lafını esirgemez & Pasiftir \\
Kaba, serttir & İnce düşüncelidir \\
Kendinden emindir & Başkalarını anlayışla karşılar \\
Saf tutar & Başkalarıyla ilişkilerde samimidir \\
\hline
\end{tabular}

Tablo analiz edildiğinde göze çarpan en önemli noktalardan biri, erkeksi özelliklerden birçoğunun pozitif değer yüklü olduğu, kadınsı özelliklerinse negatif değer yüklü olduğudur. Örneğin; aktif, rekabetçi, bağımsız ve kendinden emin olmak genel anlamda toplumsal yaşamda aranan, istenilen niteliklerdir ve erkeğe atfedilmiştir. Öte yandan; kolayca ağlamak ve incinmek, büyük kriz anlarında heyecanlanmak, onaylanmaya ihtiyaç duymak ve pasif olmak gibi niteliklerse olumsuz çağrışımlar yapmaktadır ve kadına atfedilmiştir. Toplumsal hafızada yer edinmiş bu kalıp yargısal toplumsal cinsiyet anlayışları yalnızca ataerkil düzeni yeniden üretip kadını "tartışılması gereken" bir konuma koymakla kalmaz, bu tarz bir toplumsal cinsiyet eşitsizliğini inşa ederken aynı zamanda erkeğin omuz-

6 L. E. Berk, Child Development, 7th ed., Boston, Pearson Education, 2006, s. 521. 
larına da önemli bir yük bindirir. Öyle ki, ataerkil anlayış içerisinde kalıp yargısal olarak kadınsı olarak nitelenen özelliklerden birini veya ikisini taşıyan bir erkeğin erkekliği doğrudan tartışmaya ve eleştiriye açılır. Ataerkil düzen içerisinde erkek, sürekli olarak erkekliğini kanıtlamak zorunda kalır. Dolayısıyla da ataerkil düzen erkeğe imtiyazlar tanıdığı gibi, erkeği bir tür ataerkillik testine tabi tutar ve bu testte başarılı olmasını bekler. Aksi takdirde, toplumdaki ideal erkeklik tipinin (yani hegemonik erkekliğin) erkekten talep ettiği beklentiler karşılanamıyor demektir ve bu da bir erkeklik krizine zemin hazırlar.

Erkekliğin daha önce düşünüldüğü gibi verili ve tartışmaya kapalı bir kategori olmadığının anlaşılmasıyla birlikte, zengin bir araştırma sahası ortaya çıkmıştır. Snel1, 1989 yılında erkeklik nosyonunun yeterince iyi kavramsallaştırılmadığını öne sürmüş ve The Masculine Behavior Scale (Erkeksi Davranış Ölçeği) adlı çalışmasıyla kalıp yargısal olarak erkeğe ve kadına atfedilen davranışsal eğilimleri değerlendirmek istemiştir. Araştırmacı bu eğilimleri şu başlıklar altında toplamıştır: kısıtlı duygusallık, kısıtlanmış sevgi, başarıya adanma ve abartılı özgüven. Kısıtlı duygusallık "özelde hissedilen duyguların kamusal kısıtlayıcılığıyla nitelenen davranışlar", kısıtlanmış sevgi "sevilen kişilere karşı hislerin kısıtlanmasını niteleyen davranışlar", başarıya adanma "başarı elde etmekle aşırı derecede ilgilenmeyi niteleyen davranışlar" ve abartılı özgüven "abartılı bir özgüven ve kişisel kontrol endişesini niteleyen davranışlar" olarak tanımlanmaktadır". Eski tarihli olmasına rağmen, bu ölçeğin maddelerinin erkeklik rollerini saptama konusunda geçerliliğini hâlâ koruduğu düşünülmektedir. Erkeklik çalışmalarının Türkiye'de görece geç yaygınlaşmasına istinaden ölçeğin Türkçe alanyazına kazandırılmamış olması da anlaşılır bir hâl almaktadır. Buradan hareketle, mevcut çalışmanın amacı, erkeksi davranışların araştırılmasındaki geçerliliğini muhafaza eden Erkeksi Davranış Ölçeğini Türkçe alanyazına kazandırmaktır.

\section{Yöntem}

\section{Çalışma Grubu}

Mevcut ölçeğin psikometrik özelliklerinin tespitini yapmak üzere Aksaray ilindeki üniversite öğrencilerinden destek alınmıştır. Öğrencilerin yaşları 18 ile $41(\mathrm{M}=20.99, \mathrm{SD}=2.10)$ arasında değişen uygun örnekleme ile seçilmiş 602 yetişkin bireydir. Uygun örnekleme tekniğinden yararlanılmasının sebebi dönem sonu sınavlarının yaklaşmasından dolayı araştırmaya hız kazandırmak ve araş-

7 W. E. Snell, "Development and Validation of the Masculine Behavior Scale: A Measure of Behaviors Stereotypically Attributed to Males vs. Females”, Sex Roles, 21, 1989, s. 749-767.

8 W. E. Snell, The Masculine Behavior Scale (MBS), Measurement Instrument Database for the Social Sciences, s. 3. 
tırmacıların kolay ulaşabileceği gönüllü katılımcıların bulunmasıdır. Katılımcıların 450'si (\%74.80) kadın ve 152'si (\%25.20) erkektir. Kadınların nicelik olarak fazla olmasının sebebi veri toplanan bölümlerde kadın nüfusunun yoğun olmasındandır (Ör: Sosyoloji, İngiliz Dili ve Edebiyatı gibi). Çalışma grubuna dâhil olan kişilerin 240’1 (\%30.90) romantik bir partnere sahip iken 362'sinin (\%60.10) romantik partneri yoktur.

\section{Veri Toplama Araçları}

Erkeksi Davranış Ölçeği-EDÖ (The Masculine Behavior Scale-MBS): Yetişkinlerin erkekliğe yüklenmiş duygu, davranış ve özelliklere ne derece sahip olduğunu ölçmek için Snell ${ }^{9}$ tarafından geliştirilen Erkeksi Davranış Ölçeği, 20 madde ve 4 alt boyuttan oluşmaktadır. Ölçek " $\mathrm{A}=$ Kesinlikle Katılmıyorum, $\mathrm{B}=$ Katılmıyorum, $\mathrm{C}=$ Kararsizım, $\mathrm{D}=$ Katıliyorum ve $\mathrm{E}=$ Kesinlikle Katıliyorum” arasinda 5'li Likert tipi kategoriye sahiptir. Ölçekten elde edilebilecek puanlar -40 ile +40 arasında değişmektedir. AFA sonucu faktör yük değerleri AFA sonucu madde faktör yük değerleri Başarıya Adanma alt boyutu için.82, .85, .78, .56 ve.77; Kısıtlı Duygusallık alt boyutu için .85, $.55, .86, .85$ ve .68; Kısıtlanmış Sevgi alt boyutu için $83, .81, .70, .52$ ve.77; Abart1l1 Özgüven ve Kontrol alt boyutu için .38, .58, $.38, .65$ ve .69 olarak saptanmıştır. Ölçeğin Cronbach alfa iç tutarlık güvenirlik katsayısı Başarıya Adanma alt boyutu için $\alpha=.87$; Kısıtlı Duygusallık alt boyutu için $\alpha=.89$; Kısıtlanmış Sevgi alt boyutu için $\alpha=.89$; Abartılı Özgüven ve Kontrol alt boyutu için $\alpha=.69$ olarak hesaplanmıştır. Ayrıca 4 hafta arayla uygulanmış test tekrar test güvenirlik katsayıları Başarıya Adanma alt boyutu için $\mathrm{r}=.62$; Kısıtlı Duygusallık alt boyutu için r=.70; Kısıtlanmış Sevgi alt boyutu için $r=.65$; Abartılı Özgüven ve Kontrol alt boyutu için $\mathrm{r}=.48$ olarak tespit edilmiştir.

Bem Cinsiyet Rolleri Envanteri (BCRE): Bireylerin toplumsal cinsiyet rollerine ilişkin düşünce ve davranış düzeylerini ölçmek amacıyla Bem ${ }^{10}$ tarafindan geliştirilen ölçeğin orijinali 20 kadınsılık, 20 erkeksilik ve 20 nötr (dolgu) maddesi olmak üzere toplamda 60 maddeden oluşmaktadır. Daha sonra Bem ${ }^{11}$ ölçeği revize etmiş; 10 kadınsılık, 10 erkeksilik ve 10 nötr olmak üzere toplamda 30 maddelik yeni bir form oluşturmuştur. Yedili Likert (1=Tamamıyla doğru değil, 7=Tamamıyla doğru) tipi bir ölçektir. Ölçeğin Türkçeye uyarlanması Özkan ve

9 Snell, Development and Validation of the Masculine Behavior Scale: A Measure of Behaviors Stereotypically Attributed to Males vs. Females.

10 S. L. Bem, "The Measurement of Psychological Androgyny", Journal of Consulting and Clinical Psychology, 42, 2, 1974, s. 155-162.

11 S. L. Bem, Bem Sex Role Inventory: Professional Manual, Palo Alto, Consulting Psychologists Press, 1981. 
Lajunen $^{12}$ tarafindan yapılmıştır. Kadınlarda Cronbach alfa iç tutarlık güvenirlik değeri erkeksilik alt ölçeği $\alpha=.80$, kadınsılık alt ölçeği için $\alpha=.66$; erkeklerde ise erkeksilik alt ölçeği $\alpha=.80$, kadınsılık alt ölçeği için $\alpha=.73$ olarak saptanmıştır. Cronbach alfa iç tutarlık güvenirlik değerleri bu çalışmada iki alt ölçek için $\alpha=.70$ olarak bulunmuştur.

\section{İşlem}

Erkeksi Davranış Ölçeğinin adaptasyon uygulamaları için, ölçeğin sahibi W. E. Snell ile 10 Eylül 2019 tarihinde ResearchGate İnternet sitesi üzerinden iletişime geçilmiş, ölçeğin Türk kültürüne adapte edilip edilemeyeceğine dair gerekli izin istenmiş ve alınmıştır. Ölçeğin Türk diline çevrilmesi sürecinde ileri çeviri deseni kullanılmıştır. İlk olarak, araştırmacılar ölçek maddelerini Türkçeye çevirmiş, daha sonra söz konusu maddelerin bulunduğu formlar İngiliz Dili ve Edebiyatı doktorasına sahip 5 uzmana gönderilmiş, görüş ve varsa düzeltme istenmiş; dilsel eşdeğerliğine bakılmıştır. Uzmanlardan gelen çeviri olurları üzerinde kritik yapılmış, içerik ve anlam bakımından gerekli iyileştirmeler yapılmıştır. Hazırlanan son Türkçe deneme formu, sosyo demografik bilgi formu ve ölçüt geçerliliği için diğer ölçek birleştirilerek uygulama formu oluşturulmuş, bu form çoğaltılarak üniversite öğrencilerine daha önce belirlenen saatte araştırmacılar tarafindan uygulanmıştır. Uygulamaya başlamadan önce gönüllü olmayanların çıkabileceği belirtilmiş, kalan öğrencilere uygulama yönerge ve kuralları açıklanmıştır. Kişilerin özel bilgileri olduğu için özellikle isim yazmamaları gerektiği, formdaki ifadelere içtenlikle ve boş bırakmadan cevap vermeleri gerektiği hatırlatılmış ve formlar dağıtılmıştır. Ortalama 20 dakika süren uygulama sonrasında dağıtılan bu formlar toplanmıştır. Yazılı verilerin sanal verilere dönüşümü araştırmacılar tarafından ayrı ayrı yapılıp, veri kaybı en aza indirgenmiş ve veri hata kontrolü yapılmıştır.

\section{Verilerin Analizi}

Verilerin istatistiksel olarak çözümlenmesinde hangi tekniklerin kullanılacağına karar verebilmek için öncelikle Kolmogorov-Smirnov, Cook's ve Leverage değerlerine bakılarak normallik ve uç değerler sınanmıştır. Veri setinin normal dağılım sergilediği ve uç değer olmadığ 1 görülmüştür. Erkeksi Davranış Ölçeği'nin psikometrik değerlerini belirlemek amaciyla dilsel kapsam geçerliği, yap1 geçerliği, ölçüt bağıntılı geçerlik, iç tutarlık güvenirliği ve madde analizi yöntemleri kullanılmıştır. Erkeksi Davranış Ölçeği’nin yap1 geçerliği için veri

12 T. Özkan - T. Lajunen, "Masculinity, Femininity, and the Bem Sex Role Inventory in Turkey", Sex Roles, 52, 1-2, 2005, s. 103-110. 
setine Açıklayıcı Faktör Analizi (AFA) ile birinci ve ikinci düzey Doğrulayıcı Faktör Analizi (DFA) uygulanmıştır. Bir veri seti üzerinde faktör analizi yapabilmek için veri setinin faktör analizine uygun olması ve örneklem sayısının yeterli olması varsayımı sorgulanmalıdır ${ }^{13}$. Dolayısıyla bunun için Bartlet Küresellik Testi ve Kaiser-Meyer Olkin (KMO) Testi sonuçları incelenmiştir. Faktör analizi basit madde analizlerine göre bir yapıyı en iyi açıklayan (varyans miktarı açısından) faktörleşebilirliğin saptanmasında oldukça etkili bir yöntemdir. AFA yapılmasının nedeni, en uygun faktör sayısını saptamak ve ölçülen maddelerin çeşitli gizil boyutunun makul göstergeleri olup olmadığını ortaya çıkarmaktır ${ }^{14}$. Diğer yandan DFA kullanılmasının sebebi, kuramsal açıdan ortaya konan faktörler ya da AFA sonucu ortaya çıkan faktörler ile maddeler arasında uyumluluk bulunup bulunmadığını test etmektir ${ }^{1516}$. DFA uyum indeksleri değerlendirilirken SRMR (Standartlaştırılmış artıkların kareleri ortalamasının karekökü), RMSEA (Yakınsama hatalarının kareleri ortalamalarının karekökü), RFI (Göreli Uyum İndeks), NNFI (Normlaştırılmamış Uyum İndeksi), IFI (Fazlalık uyum indeksi), GFI (Düzeltilmiş Uyum İyiliği İndeksi), CFI (Karşılaştırılmalı Uyum İndeksi) katsayılarından faydalanılmıştır. Yapının uyum iyiliği ölçütleri olarak $\chi^{2} / \mathrm{sd} \leq 3$, CFI, GFI, IFI, NFI, RFI $\geq .90$, RMSEA $\leq .80$ değerleri kabul edilmiştir ${ }^{16171819}$. Ayrıca Kline ${ }^{20}$ uyum iyiliği değerleri için $\chi^{2} / \mathrm{sd} \leq 2$, CFI, GFI, IFI, NFI, RFI $\geq .95$, RMSEA $\leq$ .50 olursa çok iyi uyum olduğunu belirtmiştir. Ölçüt bağıntılı geçerlik için BCRÖ kullanılmıştır. Güvenirlik analizinde Cronbach alfa iç tutarlık güvenirlik katsay1sına bakılmıştır. Cortina ${ }^{21}$, Cronbach alfa iç tutarlık güvenirlik katsayısının karş1laştırma gruplarında .70 ile .80 arasında bir değerin kabul edilebilir olduğunu ak-

13 S. A. Mulaik, Foundations of Factor Analysis, 2nd ed., Chapman and Hall/CRC Press, 2009.

14 T. A. Brown - M. T. Moore, "Confirmatory Factor Analysis", Handbook of Structural Equation Modeling, ed. R. H. Hoyle, New York, Guilford Press, 2012, s. 361-379.

15 H. Sarıçam - A. Mert - İ. Çelik, "Güçlü Yönler Öz-yeterlik Ölçeğinin Türkçe Versiyonunun Psikometrik Özellikleri”, OPUS Uluslararası Toplum Araştırmaları Dergisi, 14, 20, 2019, s. 288-313.

16 Brown - Moore, a.g.e.

17 Ü. Erkorkmaz - İ. Etikan - O. Demir - K. Özdamar - S. Y. Sanisoğlu, "Doğrulayıcı Faktör Analizi ve Uyum İndeksleri”, Türkiye Klinikleri Journal of Medical Sciences, 33, 1, 2013, s. 210-223.

18 R. B. Kline, Principle and Practice of Structural Equation Modelling, 4th ed., New York, The Guilford Press, 2016.

19 H. Sarıçam - F. F. Adam Karduz, "Sosyal Medya Kullanım Bozukluğu Ölçeğinin Türk Kültürüne Uyarlanması: Geçerlik ve Güvenirlik Çalışması”, Eğitimde ve Psikolojide Ölçme ve Değerlendirme Dergisi, 9, 2, 2018, s. 116-135.

20 Kline, a.g.e.

21 J. M. Cortina, "What is Coefficient Alpha? An Examination of Theory and Applications", Journal of Applied Psychology, 78, 1, 1993, s. 98-104. 
tarmıştır. Madde analizlerinde tutarlılığ 1 değerlendirebilmek adına madde alt-üst \%27 değerleri ile düzeltilmiş madde toplam korelasyon katsayıları irdelenmiştir. Analizlerde yapılacak kestirimlerin güvenirliği açısından güven düzeyi parametresi olarak \%95 $(\mathrm{p}<.05)$ tercih edilmiş, verilerin istatiksel tahlilinde SPSS 17 ve Lisrel 8.8 istatistik paket programlarından faydalanılmıştır.

\section{Bulgular}

\section{Dil Kapsam Geçerliği}

Mevcut ölçeğin dil kapsam geçerliği çalışması sürecinde Davis ${ }^{22}$ tekniğinden esinlenilmiştir. Davis tekniğinde uygunluk derecelendirmesi olarak dört şık (a-Uygundur, b-K1smen uygundur, c-Revize edilmesi lazım ve d-Uygun değildir gibi) verilir. Kapsam geçerlik indeksi hesaplanırken (a) ve (b) görüşlerini belirten uzmanların sayısı, toplam görüş bildiren uzman sayısına bölünür. Bu çalışmada Lynn'in ${ }^{23}$ tavsiyesine dayanarak uzmanlardan 3'lü (1=Maddenin uyarlamas1 uygun, 2=Maddenin uyarlamasında düzeltme gerekli, 3=Maddenin uyarlaması uygun değildir) derecelendirme istenmiştir. Ayrıca uzman dönütlerinde uygunluk yüzdeleri de hesaplanmıştır.

Tablo 2: Dil Kapsam Geçerlik İndeks (DKGí) Değerleri

\begin{tabular}{llllll}
\hline Madde no & DKGI & \% & Madde no & DKGi & \% \\
\hline ed1 & .80 & 86.67 & a11 & .80 & 86.67 \\
ed2 & .80 & 86.67 & ed12 & 1.00 & 91.66 \\
ed3 & .80 & 75 & ed13 & 1.00 & 100 \\
ed4 & 1.00 & 91.66 & ed14 & .80 & 86.67 \\
ed5 & .80 & 86.67 & ed15 & 1.00 & 100 \\
ed6 & .80 & 86.67 & ed16 & 1.00 & 100 \\
ed7 & .80 & 86.67 & ed17 & 1.00 & 91.66 \\
ed8 & .80 & 86.67 & ed18 & 1.00 & 100 \\
ed9 & .80 & 86.67 & ed19 & 1.00 & 100 \\
ed10 & .80 & 100 & ed20 & 1.00 & 100 \\
\hline
\end{tabular}

22 L. L. Davis, "Instrument Review: Getting the Most from a Panel of Experts", Applied Nursing Research, 5, 4, 1992, s. 194-197.

23 M. R. Lynn, "Determination and Quantification of Content Validity", Nursing Research, 35, 6, 1986, s. 382-385. 
Tablo 2 incelendiğinde maddelerin dil kapsam geçerlik indeks değerleri, 0.80 ile 1.00 arasında değişiklik göstermektedir. Davis ${ }^{24}$ kapsam geçerlik indeks değerlerinin .80 'den büyük olması gerektiğini belirtmektedir. Bu bağlamda uygunluk yüzdelerine de dayanarak Erkeksi Davranış Ölçeği'nin dil kapsam geçerlik indekslerinin gerekli ölçütü sağladığı söylenebilir. Ölçeğin 9 maddesi için DGKİ katsayısı en üst düzeyde (1.00) ve 7 madde için çeviri uygunluk yüzdesi \%100'dür. Üçüncü maddede ("Profesyonel bir kariyer arayış1 için kapsamlı zaman ve çaba harcarım"). çeviri uygunluk yüzdesi diğerlerine göre daha düşüktür. Bunun anlatım bozukluğundan kaynaklandığı söylenebilir.

\section{Yapı Geçerliğ i}

Açıklayıcı Faktör Analizi (AFA): Çalışma grubundan ilk veri setine uygulanan AFA sonucu Bartlet Küresellik Testi değerinin $\chi^{2}=2074.986 \mathrm{sd}=190(\mathrm{p}=.000)$ ve KMO örneklem uygunluk katsayısının .80 olduğu görülmüştür. Hair vd ${ }^{25}$ göre Bartlet Küresellik Testi sonucunun istatistiksel olarak anlamlı olması ve KMO değerinin 0.80 ile 0.90 arasında olması, örneklemin uygulama için uygunluğunu ve verilerin çok değişkenli normallik varsayımlarını karşıladığını göstermektedir. Ayrıca Temel bileşenler analizine dayalı olarak, ölçeğin orijinal yapısıyla uygun olan 20 maddelik dört boyutlu modeli, ölçeğin toplam varyansının \%56.50'sini açıklamaktadır. Varimax dik döndürme yöntemi sonucu madde faktör yükleri Başarıya Adanma alt boyutu için .72 ile .81; Kısıtlı Duygusallık alt boyutu için .56 ile .77; Kısıtlanmış Sevgi alt boyutu için .56 ile .79 ve Abartılı Özgüven ve Kontrol alt boyutu için .54 ile .76 arasında sıralanmaktadır (Bkz. Tablo 3).

Tablo 3: AFA Sonucu Madde Faktör Yükleri

\begin{tabular}{llcccc}
\hline Madde no & \multicolumn{2}{c}{ Bileşen } & Madde no & \multicolumn{2}{c}{ Bileşen } \\
& $\mathbf{1}$ & $\mathbf{3}$ & & $\mathbf{2}$ & $\mathbf{4}$ \\
\hline ed1 & .81 & a11 & .77 & \\
ed2 & .79 & ed12 & .65 \\
ed3 & .78 & ed13 & .79 \\
ed4 & .72 & ed14 & .56 \\
ed5 & .75 & ed15 & .78
\end{tabular}

24 Davis, a.g.e.

25 J. F. Hair Jr. - R. E. Anderson - R. L. Tatham - W. C. Black, Multivariate Data Analysis with Readings, New Jersey, Prentice Hall, 1995. 


\begin{tabular}{|c|c|c|c|c|c|}
\hline ed6 & & .66 & ed16 & & .54 \\
\hline ed7 & & .66 & ed17 & & .58 \\
\hline ed8 & & .77 & ed18 & & .73 \\
\hline ed9 & & .78 & ed19 & & .73 \\
\hline ed10 & & .56 & ed20 & & .76 \\
\hline Toplam & 16.20 & 13.68 & & 14.22 & 12.39 \\
\hline
\end{tabular}

Doğrulayıcı Faktör Analizi (DFA): Yapı geçerliğinde, AFA'dan elde edilen modelin doğrulanması için ikinci bir diğer gruptan elde edilen veri setine birinci düzey DFA uygulanmıştır. En Çok Olabilirlik yöntemine dayalı DFA, uyum indeksi değerleri $\chi^{2}=420.50, \mathrm{sd}=164\left(\chi^{2} / \mathrm{sd}=2.56\right), \mathrm{RMSEA}=.072, \mathrm{CFI}=.92, \mathrm{GFI}=.90$, $\mathrm{IFI}=.92, \mathrm{NNFI}=.90$ ve SRMR=.072 olacak şekilde hesaplanmıştır (Bkz. Şekil 1).

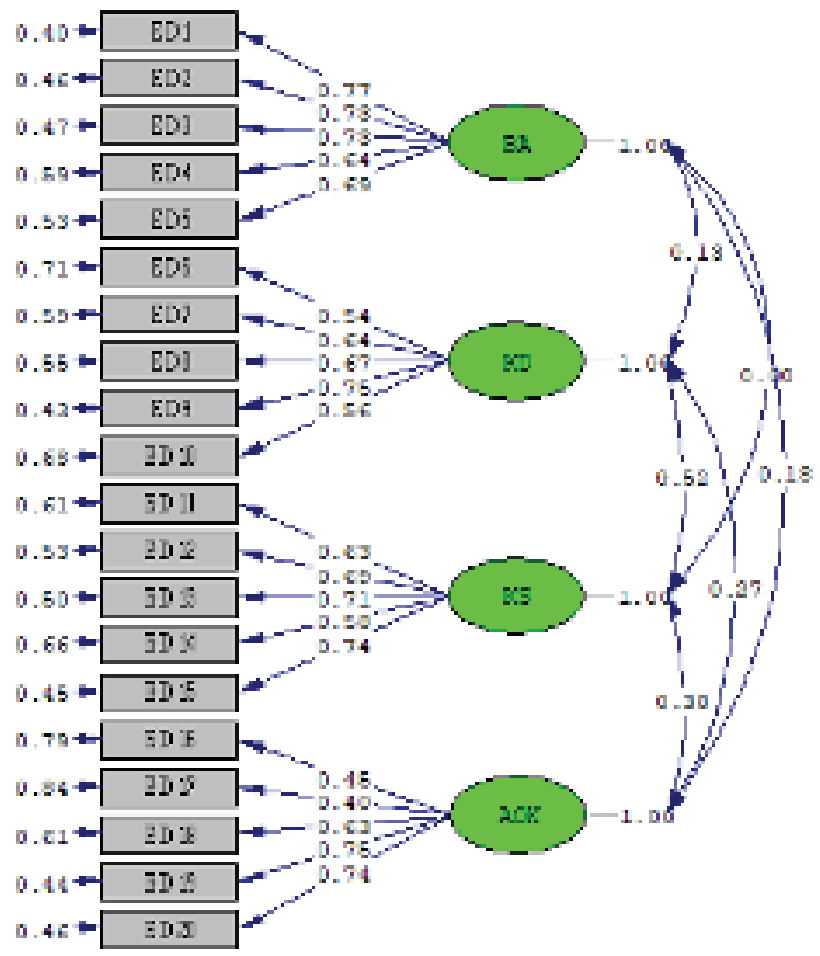

Ch1-square-420.50, df-164, P-value-0.00000, suszh-0.072

Şekil 1. Birinci Düzey DFA Madde Faktör Yük İndeksleri 
Şekil 1 incelendiğinde görülebileceği üzere, ölçeğin yirmi maddeden oluşan dört boyutlu modelin birinci düzey DFA sonucu madde faktör yük indeksleri $(\lambda)$ Başarıya Adanma alt boyutu için .64 ile .77; Kısıtlı Duygusallık alt boyutu için .54 ile .67; Kısıtlanmış Sevgi alt boyutu için .58 ile .74 ve Abartılı Özgüven ve Kontrol alt boyutu için .40 ile .75 arasındadır.

Çok boyutlu bir model olduğu için yapı geçerliliği ikinci düzey DFA ile tekrar sınanmıştır. Buna göre birinci düzey DFA uyum indeksi değerleri $\chi^{2}=430.58$, $\mathrm{sd}=166\left(\chi^{2} / \mathrm{sd}=2.59\right), \mathrm{RMSEA}=.072, \mathrm{CFI}=.91, \mathrm{GFI}=.89, \mathrm{IFI}=.91, \mathrm{NNFI}=.90$ ve $\mathrm{SRMR}=.080$ olarak bulunmuştur ve path diyagramı Şekil 2'de gösterilmiştir.

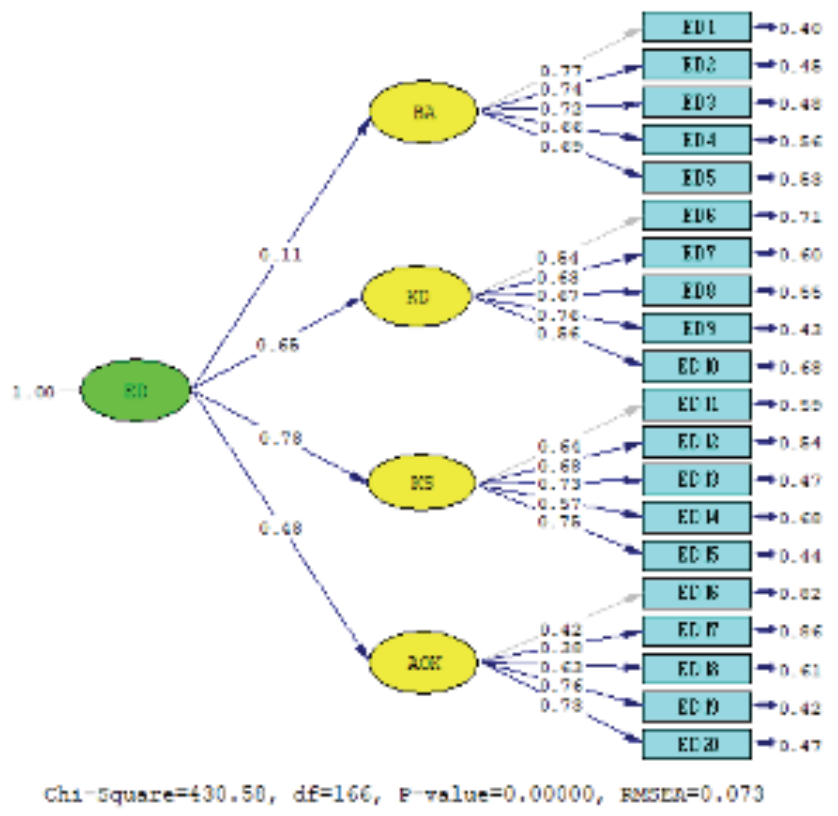

Şekil 2. İkinci Düzey DFA Madde Faktör Yük İndeksleri

Şekil 2'de gibi ölçeğin yirmi maddeden oluşan dört boyutlu modelin ikinci düzey DFA sonucu madde faktör yük indeksleri $(\lambda)$ Başarıya Adanma alt boyutu için .66 ile .77; Kısıtlı Duygusallık alt boyutu için .54 ile .76; Kısıtlanmış Sevgi alt boyutu için .57 ile .75 ve Abartılı Özgüven ve Kontrol alt boyutu için .38 ile .76 arasindadir.

\section{Ölçüt Bağıntılı Geçerlik}

Erkeksi Davranış Ölçeği’nin ölçüt bağıntılı geçerlik çalışması esnasında Bem Cinsiyet Rolleri Ölçeği ile ilişki düzeyleri Pearson korelasyon testiyle incelen- 
miştir. Başarıya adanma ve aşırı özgüven ve kontrol ile erkeksilik arasında $\mathrm{p}<.01$ önem düzeyinde sırasıyla $r=.24, .27$ pozitif ilişkiler bulunmuştur. Başarıya adanma ve aşırı özgüven ve kontrol ile kadınsılık arasında $\mathrm{p}<.01$ önem düzeyinde sırasıyla $\mathrm{r}=.29, .23$ pozitif ilişkiler bulunmuştur. (Bkz. Tablo 4).

Tablo 4: Ölçeklere ve alt boyutlarına ait betimleyici veriler

\begin{tabular}{lllllll}
\hline Alt boyutlar & 1. BA & 2. KA & 3. KS & 4.AOK & 5.E & 6.K \\
\hline 1. BA & - & $.13^{*}$ & .00 & $.21^{* *}$ & $.24^{* *}$ & $.29^{* *}$ \\
2. KA & & - & $.43^{* *}$ & $.21^{* *}$ & .03 & .01 \\
3. KS & & & - & $.30^{* *}$ & .00 & .02 \\
4. AOK & & & & - & $.27^{* *}$ & $.23^{* *}$ \\
5. Erkeksilik & & & & & - & $.41^{* *}$ \\
6. Kadinsilık & & & & & & - \\
Ortalama & 2.55 & .94 & -1.13 & 1.93 & 49.01 & 55.90 \\
Ss & 4.38 & 4.72 & 4.94 & 4.48 & 8.31 & 9.20 \\
Cronbach alfa & .84 & .77 & .80 & .73 & .70 & .70 \\
\hline
\end{tabular}

${ }^{*} \mathrm{p}<.05 ;{ }^{* *} \mathrm{p}<.01 \mathrm{BA}=$ Başarıya Adanma, KA=Kısıtlı Duygusallık, KS=Kısıtlanmış Sevgi, AOK=Abart11 Özgüven ve Kontrol

\section{Güvenirlik}

Ölçeğin güvenirlik çalışmaları Cronbach alfa iç tutarlık güvenirlik katsay1s1 Başarıya Adanma alt boyutu için $\alpha=.84$; Kısıtlı Duygusallık alt boyutu için $\alpha=.77$; Kısıtlanmış Sevgi alt boyutu için $\alpha=.80$; Abartılı Özgüven ve Kontrol alt boyutu için $\alpha=.73$ ve ölçeğin bütünü için için $\alpha=.81$ olacak şekilde hesaplanmıştır. Cortina ${ }^{26}$, Cronbach $\alpha$ değerinin en az .70 olması gerektiğini belirtilmiştir.

\section{Madde Analizleri}

Erkeksi Davranış Ölçeği’nin madde tutarlılıkları için öncelikle düzeltilmiş madde toplam korelasyon katsayılarına bakılmıştır. Bunun sonucunda bu katsayıların .41 ile .68 arasında değiştiği saptanmıştır. Düzeltilmiş madde toplam 
korelasyon katsayıları için alanyazındaki ölçüt .30'dan büyük olmasıdır ${ }^{27}$. Tüm maddeler genelinde bu ölçütün sağlandığını söylemek mümkündür. Bunun yanı sıra, her maddeye ait alt-üst $\% 27$ madde ayırt edicilik indekslerine bakılmış ve t değerlerinin $\mathrm{p}<01$ önem düzeyinde -24.18 ile -61.98 arasında farklılaştığ tespit edilmiştir (Bkz. Tablo 5).

Tablo 5: Madde Toplam Korelasyon ve Madde Ayırt Edicilik İndeksleri

\begin{tabular}{llllll}
\hline $\begin{array}{l}\text { Madde } \\
\text { no }\end{array}$ & $\mathbf{R}_{\mathrm{jx}}$ & $\begin{array}{l}\text { Alt-üst \%27 madde } \\
\text { ayırt edicilik indeksi }(\mathbf{t})\end{array}$ & $\begin{array}{l}\text { Madde } \\
\mathbf{n o}\end{array}$ & $\mathbf{R}_{\mathrm{jx}}$ & $\begin{array}{l}\text { Alt-üst \%27 madde } \\
\text { ayırt edicilik indeksi (t) }\end{array}$ \\
\hline ed1 & .68 & $-24.18^{* *}$ & $\mathbf{e d 1 1}$ & .57 & $-61.98^{* *}$ \\
ed2 & .66 & $-26.92^{* *}$ & $\mathbf{e d 1 2}$ & .59 & $-42.80^{* *}$ \\
ed3 & .63 & $-28.14^{* *}$ & $\mathbf{e d 1 3}$ & .62 & $-46.06^{* *}$ \\
ed4 & .61 & $-30.53^{* *}$ & $\mathbf{e d 1 4}$ & .49 & $-45.49^{* *}$ \\
ed5 & .64 & $-27.92^{* *}$ & $\mathbf{e d 1 5}$ & .65 & $-41.70^{* *}$ \\
ed6 & .48 & $-47.83^{* *}$ & $\mathbf{e d 1 6}$ & .41 & $-35.50^{* *}$ \\
ed7 & .55 & $-47.73^{* *}$ & $\mathbf{e d 1 7}$ & .41 & $-28.97^{* *}$ \\
ed8 & .57 & $-41.16^{* *}$ & $\mathbf{e d 1 8}$ & .51 & $-43.86^{* *}$ \\
ed9 & .63 & $-40.19^{* *}$ & $\mathbf{e d 1 9}$ & .56 & $-43.68^{* *}$ \\
ed10 & .46 & $-43.20^{* *}$ & $\mathbf{e d 2 0}$ & .58 & $-38.75^{* *}$ \\
\hline
\end{tabular}

$* * \mathrm{p}<.01$

\section{Sonuç ve Değerlendirme}

Üniversite öğrencilerinde Erkeksi Davranış Ölçeğinin geçerlik ve güvenirliğinin test edildiği bu çalışmada ölçeğin bir takım psikometrik değerleri incelenmiştir. İlk olarak dilsel eşdeğerlik incelenmiştir. Her bir maddenin hem Türkçe hem de İngilizceleri için 5 uzmandan gelen dönütlere dayalı olarak hesaplanan dil kapsam geçerlik indeks değerleri alanda ölçüt olarak kabul edilen .80 'den ${ }^{28}$ büyüktür. Bu bağlamda ölçeğin dilsel olarak geçerli olduğunu söylemek mümkündür. Yapı geçerliği ise için iki farklı veri setine AFA ve DFA yapılmıştır. AFA sonucunda KMO katsayısının 0.80-0.90 arası olmas1 ve veri setinin 300'den fazla olması bu veri grubu bağlamında örneklem sayısının faktör analizine uygun olduğunun göstergesidir. Bunun yanı sıra, Bartlett küresellik testinin manidarlık 
değeri .05 alfa değerinden düşük olduğundan verilerin çok değişkenli normallik varsayımlarını sağladığ söylenebilir ${ }^{2930}$. Bununla birlikte, her bir faktör altındaki madde yük değerlerinin alanyazında ölçüt kabul edilen .32 ' den $^{31}$ büyük olması maddenin ilgili faktörde makul göstergeye sahip olduğunun ispatıdır. Ölçeğin orijinali ve şu an yapılan AFA sonucu ortaya çıkan yapının Türk kültüründe yetişmiş üniversite öğrencilerinde doğrulanıp doğrulanmadığını belirlemek için birinci ve ikinci düzey DFA sonucu uyum indeksi değerlerinden $\chi^{2} / \mathrm{sd}$, CFI, GFI, IFI, NNFI, SRMR değerleri alanyazında belirtilmiş olan ölçütlere $\left(2 \leq \chi^{2} / \mathrm{sd} \leq 3, .90 \leq \mathrm{CFI}\right.$ $\leq .95,90 \leq \mathrm{GFI} \leq .95,90 \leq \mathrm{IFI} \leq .95,90 \leq \mathrm{NNFI} \leq .95, .05 \leq \mathrm{SRMR} \leq .08$ ve .05 $\leq$ RMSEA $\leq .08)$ göre kabul edilebilir düzeydedir ${ }^{32333435}$. Ölçüt bağıntılı geçerlik çalışmasında Erkeksi Davranış Ölçeği'nin BCRÖ ile p<.01 önem düzeyinde .20 ile .30 arasında ilişki katsayılarına sahip olması düşük düzeyde ilişki ${ }^{36}$ olarak adlandırılsa da istatistiksel olarak anlamlı ilişkinin çıkmasından ötürü benzer ölçek geçerliliğinin sağlandığı söylenebilir.

Güvenirlik analizlerinde ölçeğe ait Cronbach alfa iç tutarlık güvenirlik katsayılarının .70’ten büyük ${ }^{37}$ olması iç tutarlık güvenirliğinin psikolojik testlerde kabul edilebilir olduğuna işaret etmektedir. Madde tutarlılığında düzeltilmiş madde toplam korelasyon katsayıları için alanyazında ölçüt kabul edilen .30 'dan yüksek $^{38}$ olması her bir maddenin ölçeğin bütünü ile gerçeklik veya doğruluk açısından benzer niteliği taşıdığının göstergesidir. Bunun dışında, her maddeye ait altüst \%27 madde ayırt edicilik indekslerinin (t) $\mathrm{p}<.01$ önem düzeyinde istatistiksel olarak anlamlı olmas ${ }^{39}$ maddelerin istenilen özelliklere sahip olan ile olmayanı ayırt edebildiğini göstermektedir. Diğer taraftan Snell' $i^{40}{ }^{40}$ geliştirmiş olduğu öl-

29 A. Basilevsky, Statistical Factor Analysis and Related Methods: Theory and Applications, John Wiley \& Sons, Inc, 1994.

30 Hair Jr. - Anderson - Tatham - Black, a.g.e.

31 J. O. Kim - C. W. Mueller, Factor Analysis: Statistical Methods and Practical Issues (Quantitative Applications in the Social Sciences), SAGE Publications Inc, 1978.

32 Brown - Moore, a.g.e.

33 Erkorkmaz - Etikan - Demir - Özdamar - Sanisoğlu, a.g.e.

34 Kline, a.g.e.

35 Sarıçam - Adam Karduz, a.g.e.

36 R. Alper, Spor Bilimlerinde Uygulamalı Istatistik, Ankara, Nobel Akademik, 2006.

37 Cortina, a.g.e.

38 Kline, a.g.e.

39 H. Sarıçam - A. Canatan, "The Adaptation, Validation, Reliability Process of the Turkish Version Orientations to Happiness Scale”, Üniversitepark Bülten, 4, 1-2, 2015, s. 7-15.

40 Snell, Development and Validation of the Masculine Behavior Scale: A Measure of Behaviors Stereotypically Attributed to Males vs. Females. 
çeğin orijinaliyle Türkçesinin psikometrik özelliklerinde birtakım farklılaşmalar görülmüştür. Orijinal formun AFA madde yük değerleri Türkçe formun madde faktör yük değerlerinden daha düşüktür. Orijinal formun güvenirlik değerlerinin ilk üç alt boyutta daha yüksek iken son alt boyutta daha düşük olduğu söylenebilir. Ayrıca Türkçe formun birinci ve ikinci düzey DFA yapılması yapı geçerliği için önemli bir katkı sağlamıştır.

Tüm bu bulgular ve deliller 1şığında dil kapsam geçerliği, yapı geçerliği, ölçüt geçerliği ve güvenirlik değerlerinden yola çıkarak Erkeksi Davranış Ölçeği'nin üniversite öğrencilerinin erkeksi davranışlarını ölçmek ve değerlendirmek için geçerli ve güvenilir bir araç olduğunu söylemek mümkündür. Diğer yandan, ölçeğin psikometrik değerlerine katkı sağlamak amacıyla aşağıdaki öneriler gerçekleştirilebilir:

Pandemi sonrası yaşanan kısıtlamalar yüzünden ölçeğin test-tekrar-test güvenirlik analizleri yapılamadığından farklı çalışmalarla test-tekrar-test güvenirlik katsayılarının hesaplanması faydalı olacaktır. Çalışmanın, Türkiye'nin farklı illerinde, seçilen farklı yetişkin gruplarıyla genişletilmesinin mevcut ölçeğin genellenebilirliği bağlamında büyük katkı sağlayacağı düşünülmektedir. 


\section{Kaynakça}

Alper, R., Spor Bilimlerinde Uygulamalı İstatistik, Ankara, Nobel Akademik, 2006.

Bal, M. D., "Toplumsal Cinsiyet Eşitsizliğine Genel Bakış", Kadın Sağlı̆̆ı Hemşireliği Dergisi, 1, 1, 2014.

Basilevsky, A., Statistical Factor Analysis and Related Methods: Theory and Applications, John Wiley \& Sons, Inc, 1994. doi: 10.1002/9780470316894.

Bem, S. L., Bem Sex Role Inventory: Professional Manual, Palo Alto, CA, Consulting Psychologists Press, 1981.

, "The Measurement of Psychological Androgyny", Journal of Consulting and Clinical Psychology, 42, 2, 1974. doi: 10.1037/h0036215

Berk, L. E., Child Development, 7th ed., Boston, Pearson Education, 2006.

Brown, T. A. - Moore, M. T., "Confirmatory Factor Analysis", Handbook of Structural Equation Modeling, ed. R. H. Hoyle, New York, Guilford Press, 2012.

Connell, R. W., Masculinities, 2nd ed. Cambridge, Polity Press, 1995.

Cortina, J. M., "What is Coefficient Alpha? An Examination of Theory and Applications", Journal of Applied Psychology, 78, 1, 1993. doi:10.1037/00219010.78.1.98

Davis, L. L., "Instrument Review: Getting the Most from a Panel of Experts", Applied Nursing Research, 5, 4, 1992. doi: 10.1016/S0897-1897(05)80008-4

Erkorkmaz, Ü. - Etikan, İ. - Demir, O. - Özdamar, K. - Sanisoğlu, S. Y., "Doğrulayıcı Faktör Analizi ve Uyum İndeksleri”, Türkiye Klinikleri Journal of Medical Sciences, 33, 1, 2013. doi: 10.5336/medsci.2011-26747

Hair Jr, J. F. - Anderson, R. E. - Tatham, R. L. - Black, W. C., Multivariate Data Analysis with Readings, New Jersey, Prentice Hall, 1995.

Kim, J. O. - Mueller, C. W., Factor Analysis: Statistical Methods and Practical Issues (Quantitative Applications in the Social Sciences), SAGE Publications, Inc, 1978.

Kline, R. B., Principle and Practice of Structural Equation Modelling, 4th ed., New York, NY, The Guilford Press, 2016.

Lynn, M. R., "Determination and Quantification of Content Validity", Nursing Research, 35, 6, 1986.

Mulaik, S. A., Foundations of Factor Analysis, 2nd ed., Chapman and Hall/ CRC Press, 2009. 
Özkan, T. - Lajunen, T., "Masculinity, Femininity, and the Bem Sex Role Inventory in Turkey", Sex Roles, 52, 1-2, 2005.

Özküralpli, İ., “Queer Teori”, Toplumsal Cinsiyet Tartısmaları, ed. F. Sayg1ligil, İstanbul, Dipnot Yayınları, 2018.

Rummel, R. J., Applied Factor Analysis, Illinois, Evanston, Northwestern University Press, 1988.

Sarıçam, H. - Adam Karduz, F. F., "Sosyal Medya Kullanım Bozukluğu Ölçeğinin Türk Kültürüne Uyarlanması: Geçerlik ve Güvenirlik Çalışması”, Ĕ̆gitimde ve Psikolojide Ölçme ve Değerlendirme Dergisi, 9, 2, 2018. doi:10.21031/ epod.335607

Sarıçam, H. - Canatan, A., "The Adaptation, Validation, Reliability Process of the Turkish Version Orientations to Happiness Scale", Üniversitepark Bülten, 4, 1-2, 2015. doi: 10.12973/unibulletin.412.1

Sarıçam, H. - Mert, A. - Çelik, İ., "Güçlü Yönler Öz-yeterlik Ölçeğinin Türkçe Versiyonunun Psikometrik Özellikleri”, OPUS Uluslararası Toplum Araştırmaları Dergisi, 14, 20, 2019. doi: 10.26466/opus.587269

Snell, W. E., "Development and Validation of the Masculine Behavior Scale: A Measure of Behaviors Stereotypically Attributed to Males vs. Females", Sex Roles, 21, 1989. doi: 10.1007/BF00289806

, The Masculine Behavior Scale (MBS), Measurement Instrument Database for the Social Sciences, https://www.midss.org/sites/default/files/mbs. pdf, Erişim Tarihi: 15.12.2019.

The Global Media Monitoring Project, GMMP 2015 Global, Regional and National Reports, 2015. http://cdn.agilitycms.com/who-makes-the-news/Imported/reports_2015/global/gmmp_global_report_en.pdf, Erişim Tarihi: 22.02.2020. 
